\title{
Effect of Fertilizer Levels, Biocompost and Biofertilizer on Content and Uptake of Nutrients of Fodder Sorghum (Sorghum bicolor (L.) Moench)
}

\author{
Chauhan Aditi ${ }^{1}$, Sonal Tripathi ${ }^{2}$, Govind $^{3}$, Satdev $^{4}$ and Narendra Singh ${ }^{2 *}$ \\ ${ }^{1}$ Department of Soil Science \& Agriculture Chem., NMCA, NAU, Navsari, India \\ ${ }^{2}$ Department of Soil Science, NAU, Navsari, India \\ ${ }^{3}$ College of Forestry, NAU, Navsari, India \\ ${ }^{4}$ Bihar Agricultural College, Sabour, Bhagalpur, India
}

*Corresponding author

\section{A B S T R A C T}

\section{Keywords}

Fertilizer levels,

Biocompost,

Biofertilizer,

Content and uptake,

Macro and micro

nutrients

Article Info

Accepted:

10 September 2019

Available Online:

10 October 2019
A field experiment was conducted at College Farm, Navsari Agricultural University, Navsari (Gujarat) during rabi season of the year 2017-18 to study the "Effect of fertilizer levels, biocompost and biofertilizer effect on yield and yield attributes of fodder sorghum. Twelve treatment combinations consisting of three levels of fertilizer, two levels of biocompost and two levels of biofertilizer were tried in factorial randomized block design with three replications. The result showed that among different treatment combinations, application of $100 \%$ RDF with biocompost and biofertilizer significantly registered maximum content and uptake of macro $\left(\mathrm{N}, \mathrm{P}_{2} \mathrm{O}_{5}\right.$ and $\mathrm{K}_{2} \mathrm{O}$ ) and micronutrients $(\mathrm{Fe}, \mathrm{Mn}, \mathrm{Zn}$ and $\mathrm{Cu}$ ). Among the different interaction, content of $\mathrm{N}$ and $\mathrm{P}_{2} \mathrm{O}_{5}$ found significant in biocompost and biofertilizer interaction. While, uptake of $\mathrm{N}, \mathrm{P}_{2} \mathrm{O}_{5}$ and micronutrients $(\mathrm{Fe}, \mathrm{Mn}, \mathrm{Zn}$ and $\mathrm{Cu}$ ) found significant in interaction of inorganic fertilizer with biofertilizer.

\section{Introduction}

Among the forage crops, sorghum (Sorghum bicolour (L.) Moench) is very popular in semiarid zones particularly more in drought-prone regions of the world (Wenzel and Van Rooyen, 2001) due to its short duration, fast growing nature, high productivity and wider adaptability to varied agro-climatic conditions. Sorghum is highly nutrient exhaustive crop, therefore, to achieve sustainable higher productivity maintenance of native soil fertility and health is necessary. The balanced and conjugated use of inorganic fertilizer, biocompost and biofertilizer in order to maintenance or adjustment of soil fertility and plant nutrient supply to an optimum level for sustaining desired crop productivity (Rakshit et al., 2008). Independent use of neither the chemical fertilizer nor an organic source can sustain the fertility of soil and productivity of crop in high input production system, whereas 
integrated nutrient management maintains soil and plant health and increase fertilizer use efficiency, content and uptake of macro and micro nutrients and ensures high crop production. This may cause a significant reduction in use of fertilizers. The inorganic fertilizer could supply only one, two or three nutrients but integrated use of inorganic fertilizers, biocompost and biofertilizer would provide macro and micronutrient to plant, soil and resist occurrence of multiple deficiencies.

In presence of organic manures, chemical fertilizers play better role with slow release of nutrients after decomposition. Organic manures have favorable influence on soil physio-chemical and biological properties which enhance crop growth and yield as well as content and uptake of nutrients (Ghuman and Sur, 2006). Use of organic manure and biofertilizers can have a greater importance in increasing availability of nutrients, fertilizer use efficiency and microbial biomass. Among several bio-agents, Azospirillum alone and in combination with PSB increases the yield of sorghum (Patidar and Mali, 2004). Therefore, introduction of efficient strain of "Azospirillium and PSB" may be helpful in boosting up production and consequently more nitrogen fixation and content and uptake of macro and micro nutrients.

Organic manure and biofertilizers are less expensive, easily available and eco-friendly expected to improve soil fertility, crop yield and content and uptake of nutrients. The introduction of efficient strains of biofertilizers in soils may help in boosting up production through increased microbial population and consequently fixation of more atmospheric nitrogen and more solubilization of insoluble phosphorus from the soil. Hence present study was undertaken to know the effect of inorganic fertilizer levels, biocompost and biofertilizer effect on content and uptake of macro and micronutrients of fodder sorghum crop.

\section{Materials and Methods}

A field experiment was conducted at the College Farm, Navsari Agricultural University, Navsari during the year 2017-18. The soil of the experimental field was clayey in texture and showed low, medium and high rating for available nitrogen $\left(255.58 \mathrm{~kg} \mathrm{ha}^{-1}\right)$, phosphorus (30.96 kg ha $\mathrm{kg}^{-1}$ and potassium $\left(592.82 \mathrm{~kg} \mathrm{ha}^{-1}\right)$, respectively. The soil was found slightly alkaline ( $\mathrm{pH} 7.85)$ with normal electric conductivity $\left(0.45 \mathrm{dsm}^{-1}\right)$. The biocompost analysis found $\mathrm{pH}$ (7.41), $\mathrm{EC}$ $\left(1.51 \mathrm{dS} \mathrm{m}^{-1}\right), \mathrm{N}(1.02 \%), \mathrm{P}_{2} \mathrm{O}_{5}(1.09 \%), \mathrm{K}_{2} \mathrm{O}$ (0.61\%), Fe (17.91 mg kg-1), Mn (1.81 mg $\left.\mathrm{kg}^{-1}\right), \mathrm{Zn}\left(0.83 \mathrm{mg} \mathrm{kg}^{-1}\right)$ and $\mathrm{Cu}\left(1.72 \mathrm{mg} \mathrm{kg}^{-1}\right)$ content (Table 1).

The treatment combination consisted of integrated nutrient management viz., $100 \%$ RDF (80:40:0 $\mathrm{kg} \quad \mathrm{NPK} / \mathrm{ha})$ without biocompost and biofertilizer $\left(\mathrm{T}_{1}\right), 100 \% \mathrm{RDF}$ + without biocompost + with biofertilizer $\left(\mathrm{T}_{2}\right)$, $100 \% \mathrm{RDF}+$ with biocompost + without biofertilizer $\left(\mathrm{T}_{3}\right), 100 \% \mathrm{RDF}+$ with biocompost + with biofertilizer $\left(\mathrm{T}_{4}\right), 75 \%$ RDF $\quad(60: 30: 0 \quad \mathrm{~kg} \quad \mathrm{NPK} / \mathrm{ha})$ without biocompost and biofertilizer $\left(\mathrm{T}_{5}\right), 75 \% \mathrm{RDF}+$ without biocompost + with biofertilizer $\left(\mathrm{T}_{6}\right)$, $75 \%$ RDF + with biocompost + without biofertilizer $\left(\mathrm{T}_{7}\right), \quad 75 \% \mathrm{RDF}+$ with biocompost + with biofertilizer $\left(\mathrm{T}_{8}\right), 50 \%$ RDF (40:20:0 kg NPK/ha) without biocompost and biofertilizer $\left(\mathrm{T}_{9}\right), 50 \% \mathrm{RDF}+$ without biocompost + with biofertilizer $\left(\mathrm{T}_{10}\right)$, $50 \% \mathrm{RDF}+$ with biocompost + without biofertilizer $\left(\mathrm{T}_{11}\right), 50 \% \mathrm{RDF}+$ with biocompost + with biofertilizer $\left(T_{12}\right)$ to fodder sorghum in rabi season. The treatments were evaluated in randomized block design (factorial) with three replications.

Fodder sorghum cv. CSV-21F was sown with spacing of $30 \mathrm{~cm}$ in the second week of November and harvested in fourth week of January during the year 2017-18. Biocompost @ $5 \mathrm{t} \mathrm{ha}^{-1}$ was applied as per treatment before 
sowing and mixed well in soil. Biofertilizers i.e. seed treatment of Azospirillum+ PSB containing $1 \times 10^{8} \mathrm{cfu} \mathrm{ml}^{-1} @ 10 \mathrm{ml} \mathrm{kg}^{-1}$ seed each and $2 \mathrm{~L} \mathrm{ha}^{-1}$ each as soil application at the time of sowing.

To determine the content and uptake of macro and micronutrients, representative green fodder samples were drawn from each plot at flowering stage. The samples were shade dried for three days, subsequently oven dried for 24 hours at $60^{\circ} \mathrm{C}$ then the samples were powdered by Willey grinder for further estimation. Dry plants were ground and composite sample was used for the determination of $\mathrm{N}, \mathrm{P}, \mathrm{K}, \mathrm{Fe}, \mathrm{Mn}$, $\mathrm{Zn}$ and $\mathrm{Cu}$ content in the plants using standard procedures (Table 2).

The uptakes of $\mathrm{N}, \mathrm{P}$ and $\mathrm{K}, \mathrm{Fe}, \mathrm{Zn}$ by plants were calculated using the following formula:

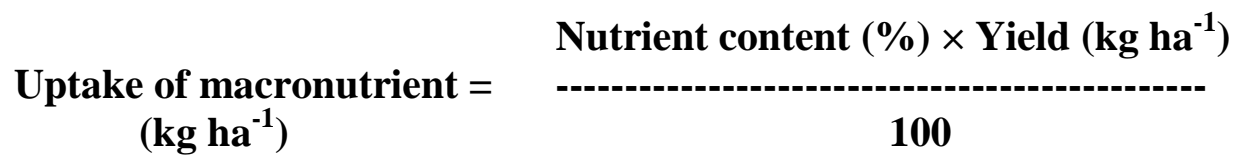

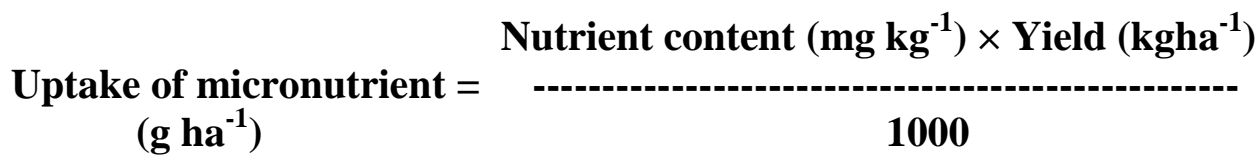

\section{Results and Discussion}

\section{Nutrient content}

Data furnished in (Table 2) indicated that the application of $100 \%$ RDF with biocompost and biofertilizer found maximum significant for content of $\mathrm{N}, \mathrm{P}_{2} \mathrm{O}_{5}$ content in plants. Among different interactions, biocompost and biofertilizer interaction found significant for $\mathrm{N}$ and $\mathrm{P}_{2} \mathrm{O}_{5}$ content of fodder sorghum (Table 3 ).

The $\mathrm{N}$ content of the plant showed significant increase with the increasing levels of $\mathrm{N}$, biocompost and biofertilizer, Azospirillium because $\mathrm{N}$ of these treatments increases the vegetative growth which leads to absorption of more $\mathrm{N}$ from soil and accumulation of $\mathrm{N}$ into plant. Similar results were revealed by other researchers (Singh and Kang, 2005; Kumar et al., 2010 and Patel et al., 2018). Increasing content of $\mathrm{P}_{2} \mathrm{O}_{5}$ in plant might be resulted due to release of growth promoting substances by Azospirillum + PSB with application of biocompost, increase in vegetative growth by $\mathrm{N}$ and healthy root development by $\mathrm{P}_{2} \mathrm{O}_{5}$. The similar results were founded by other researchers (Shekara et al., 2009; Duhan, 2013 and jat et al, 2013). While, $\mathrm{K}_{2} \mathrm{O}$ content was found non-significant.

In the case of micronutrient content, the same treatment found significantly higher for micro nutrient content but micronutrient contents found non-significant in case of different interactions (Table 2). Higher content of these micro nutrients in plants might be due to the better and healthy growth of the crop by higher application of $\mathrm{N}$ as well as biofertilizer which facilitates nutrient absorption from the soil. Micronutrients status of soil in organically treated plots might be due to release of chelating agents from organic matter decomposition which might have prevented micronutrients from precipitation, oxidation and leaching. The similar results were reported by Bhoya et al. (2013) and Singh and Sharma (2015). 
Table.1 Methods used for the determination of nutrients of plant samples

\begin{tabular}{|c|c|c|}
\hline Nutrient & Method & Reference \\
\hline Nitrogen (\%) & Modified Kjeldahl's method & Jackson (1973) \\
\hline Phosphorus (\%) & $\begin{array}{c}\text { VanadomolybdoPhosphoric acid yellow colour } \\
\text { method }\end{array}$ & Jackson (1973) \\
\hline Potassium (\%) & Flame photometer method & Jackson (1973) \\
\hline $\begin{array}{c}\text { Micronutrients } \\
\text { Fe, Mn, Zn, } \\
\mathbf{C u}(\mathbf{p p m})\end{array}$ & $\begin{array}{c}\text { Atomicabsorption spectrophotometer (AAS) } \\
\text { (1978) }\end{array}$ & $\begin{array}{c}\text { Lindsay and Norwell } \\
\text { (1978) }\end{array}$ \\
\hline
\end{tabular}

Table.2 Effect of fertilizer levels, biocompost and biofertilizer on content of macro and micronutrients

\begin{tabular}{|c|c|c|c|c|c|c|c|}
\hline \multirow[t]{2}{*}{ Treatment } & \multicolumn{3}{|c|}{ Macronutrient content $(\%)$} & \multicolumn{4}{|c|}{$\begin{array}{l}\text { Micronutrient content } \\
\left(\mathrm{mg} \mathrm{kg}^{-1}\right)\end{array}$} \\
\hline & $\mathbf{N}$ & $\mathbf{P}_{2} \mathbf{O}_{5}$ & $\mathbf{K}_{2} \mathbf{O}$ & $\mathbf{F e}$ & Mn & $\mathbf{Z n}$ & $\mathbf{C u}$ \\
\hline \multicolumn{8}{|c|}{ (A) Fertilizer levels } \\
\hline$A_{1}: 100 \%$ RDF & 1.32 & 0.96 & 2.01 & 754.52 & 24.05 & 11.18 & 9.36 \\
\hline $\mathrm{A}_{2}: 75 \% \mathrm{RDF}$ & 1.28 & 0.86 & 2.00 & 748.41 & 23.00 & 10.49 & 8.69 \\
\hline $\mathbf{A}_{3}: \mathbf{5 0} \% \mathrm{RDF}$ & 1.20 & 0.70 & 1.95 & 730.34 & 20.85 & 8.90 & 7.10 \\
\hline S.Em. \pm & 0.01 & 0.01 & 0.02 & 2.28 & 0.13 & 0.08 & 0.07 \\
\hline C.D. at $5 \%$ & 0.02 & 0.03 & NS & 6.68 & 0.37 & 0.25 & 0.22 \\
\hline \multicolumn{8}{|c|}{ (B) Biocompost (5 t ha $\left.{ }^{-1}\right)$} \\
\hline $\mathbf{B}_{1}$ : Without BC & 1.26 & 0.82 & 1.98 & 741.52 & 22.20 & 9.82 & 8.01 \\
\hline $\mathbf{B}_{2}$ : With BC & 1.27 & 0.86 & 2.00 & 747.33 & 23.07 & 10.55 & 8.75 \\
\hline S.Em. \pm & 0.005 & 0.01 & 0.02 & 1.86 & 0.10 & 0.07 & 0.06 \\
\hline C.D. at 5\% & 0.01 & 0.02 & NS & 5.46 & 0.31 & 0.20 & 0.18 \\
\hline \multicolumn{8}{|c|}{ (C) Biofertilizer (Azospirillium and PSB) $\left(10 \mathrm{ml} \mathrm{kg}^{-1}\right.$ seed $\left.+21 \mathrm{ha}^{-1}\right)$} \\
\hline $\mathrm{C}_{1}$ : Without BF & 1.25 & 0.81 & 1.99 & 741.26 & 22.06 & 9.79 & 7.98 \\
\hline $\mathrm{C}_{2}$ : With BF & 1.28 & 0.87 & 1.98 & 747.59 & 23.21 & 10.58 & 8.78 \\
\hline S.Em. \pm & 0.005 & 0.01 & 0.02 & 1.86 & 0.10 & 0.07 & 0.06 \\
\hline C.D. at $5 \%$ & 0.01 & 0.02 & NS & 5.46 & 0.31 & 0.20 & 0.18 \\
\hline $\mathrm{CV} \%$ & 1.56 & 3.81 & 3.29 & 1.06 & 1.95 & 2.88 & 3.04 \\
\hline $\begin{array}{l}\text { Significant } \\
\text { interaction }\end{array}$ & B x C & B x C & - & - & - & - & - \\
\hline
\end{tabular}


Table.3 Interaction effect of biocompost and biofertilizer on $\mathrm{N}$ content (\%) and $\mathrm{P}_{2} \mathrm{O}_{5}$ content (\%) of fodder sorghum

\begin{tabular}{|c|c|c|}
\hline Treatment interaction & N content $(\boldsymbol{\%})$ & $\mathbf{P}_{\mathbf{2}} \mathbf{O}_{\mathbf{5}}$ content $(\mathbf{\%})$ \\
\hline $\mathbf{B}_{\mathbf{1}} \times \mathbf{C}_{\mathbf{1}}$ & 1.25 & 0.80 \\
\hline $\mathbf{B}_{\mathbf{1}} \times \mathbf{C}_{\mathbf{2}}$ & 1.26 & 0.84 \\
\hline $\mathbf{B}_{\mathbf{2}} \times \mathbf{C}_{\mathbf{1}}$ & 1.25 & 0.81 \\
\hline B $_{\mathbf{2}} \times \mathbf{C}_{\mathbf{2}}$ & 1.29 & 0.91 \\
\hline S.Em. $\mathbf{\pm}$ & 0.01 & 0.01 \\
\hline C.D. at 5\% & 0.02 & 0.03 \\
\hline
\end{tabular}

Table.4 Effect of fertilizer levels, biocompost and biofertilizer on uptake of macro and micronutrients

\begin{tabular}{|c|c|c|c|c|c|c|c|}
\hline \multirow[t]{2}{*}{ Treatment } & \multicolumn{3}{|c|}{$\begin{array}{l}\text { Macronutrient uptake (kg } \\
\text { ha }^{-1} \text { ) }\end{array}$} & \multicolumn{4}{|c|}{$\begin{array}{l}\text { Micronutrient uptake } \\
\qquad\left(\mathrm{g} \mathrm{ha}^{-1}\right)\end{array}$} \\
\hline & $\mathbf{N}$ & $\mathbf{P}_{2} \mathbf{O}_{5}$ & $\mathbf{K}_{2} \mathbf{O}$ & $\mathrm{Fe}$ & Mn & $\mathbf{Z n}$ & $\mathbf{C u}$ \\
\hline \multicolumn{8}{|c|}{ (A) Fertilizer levels } \\
\hline$A_{1}: 100 \%$ RDF & 132.10 & 96.08 & 201.95 & 7578.01 & 241.69 & 112.36 & 94.12 \\
\hline $\mathrm{A}_{2}: 75 \%$ RDF & 115.75 & 78.62 & 181.30 & 6782.22 & 209.20 & 95.66 & 79.35 \\
\hline $\mathbf{A}_{3}: 50 \%$ RDF & 75.77 & 44.30 & 122.60 & 4588.39 & 131.21 & 55.93 & 44.63 \\
\hline S.Em. \pm & 3.00 & 1.92 & 4.84 & 164.22 & 5.21 & 2.41 & 1.98 \\
\hline C.D. at $5 \%$ & 8.81 & 5.63 & 14.20 & 481.63 & 15.27 & 7.07 & 5.80 \\
\hline \multicolumn{8}{|c|}{ (B) Biocompost (5 tha $\left.{ }^{-1}\right)$} \\
\hline$B_{1}$ : Without BC & 103.66 & 69.02 & 162.42 & 6080.54 & 183.75 & 81.87 & 67.07 \\
\hline $\mathrm{B}_{2}:$ With BC & 112.09 & 76.98 & 174.81 & 6551.88 & 204.32 & 94.09 & 78.33 \\
\hline S.Em. \pm & 2.45 & 1.57 & 3.95 & 134.08 & 4.25 & 1.97 & 1.61 \\
\hline C.D. at 5\% & 7.19 & 4.59 & 11.59 & 393.25 & 12.47 & 5.77 & 4.74 \\
\hline \multicolumn{8}{|c|}{ (C) Biofertilizer (Azospirillium and PSB) $\left(10 \mathrm{ml} \mathrm{kg}^{-1}\right.$ seed $\left.+2 \mathrm{l} \mathrm{ha}^{-1}\right)$} \\
\hline $\mathrm{C}_{1}$ : Without BF & 101.93 & 66.78 & 161.54 & 6011.69 & 180.40 & 80.54 & 65.92 \\
\hline $\mathrm{C}_{2}$ : With BF & 113.82 & 79.23 & 175.69 & 6620.72 & 207.66 & 95.42 & 79.48 \\
\hline S.Em. \pm & 2.45 & 1.57 & 3.95 & 134.08 & 4.25 & 1.97 & 1.61 \\
\hline C.D. at $5 \%$ & 7.19 & 4.59 & 11.59 & 393.25 & 12.47 & 5.77 & 4.74 \\
\hline CV \% & 9.64 & 9.10 & 9.95 & 9.01 & 9.30 & 9.49 & 9.42 \\
\hline $\begin{array}{l}\text { Significant } \\
\text { interaction }\end{array}$ & $\mathrm{A} \times \mathrm{C}$ & $A \times C$ & - & $A \times C$ & $\mathrm{~A} \times \mathrm{C}$ & $\mathrm{A} \times \mathrm{C}$ & $A \times C$ \\
\hline
\end{tabular}


Table.5 Interaction effect of fertilizer levels and biofertilizer macro and micronutrient uptake of fodder sorghum

\begin{tabular}{|c|c|c|c|c|c|c|}
\hline \multirow{2}{*}{$\begin{array}{c}\text { Treatment } \\
\text { interaction }\end{array}$} & \multicolumn{3}{|c|}{ Macronutrient $\left(\mathrm{kg} \mathrm{ha}^{\mathbf{- 1}}\right)$} & \multicolumn{4}{|c|}{ Micronutrient $\left.\mathbf{g ~ h a}^{-\mathbf{1}}\right)$} \\
\hline $\mathbf{A}_{\mathbf{1}} \mathbf{x} \mathbf{C}_{\mathbf{1}}$ & $\mathbf{N}$ & $\mathbf{P}_{\mathbf{2}} \mathbf{O}_{\mathbf{5}}$ & $\mathbf{F e}$ & $\mathbf{M n}$ & $\mathbf{Z n}$ & $\mathbf{C u}$ \\
\hline $\mathbf{A}_{\mathbf{1}} \mathbf{x} \mathbf{C}_{\mathbf{2}}$ & 135.79 & 91.91 & 7425.61 & 231.59 & 106.03 & 88.27 \\
\hline $\mathbf{A}_{\mathbf{2}} \mathbf{x} \mathbf{C}_{\mathbf{1}}$ & 102.62 & 100.25 & 7730.41 & 251.80 & 118.68 & 99.97 \\
\hline $\mathbf{A}_{\mathbf{2}} \mathbf{x} \mathbf{C}_{\mathbf{2}}$ & 128.88 & 96.07 & 6087.86 & 181.94 & 81.60 & 66.87 \\
\hline $\mathbf{A}_{\mathbf{3}} \mathbf{x} \mathbf{C}_{\mathbf{1}}$ & 74.37 & 42.35 & 4521.61 & 127.68 & 53.98 & 42.61 \\
\hline $\mathbf{A}_{\mathbf{3}} \mathbf{x} \mathbf{C}_{\mathbf{2}}$ & 77.17 & 46.26 & 4655.18 & 134.74 & 57.87 & 46.65 \\
\hline S.Em. $\mathbf{\pm}$ & 4.25 & 2.71 & 232.24 & 7.36 & 3.41 & 2.80 \\
\hline C.D. at 5\% & 12.45 & 7.96 & 681.13 & 21.60 & 10.00 & 8.20 \\
\hline
\end{tabular}

\section{Nutrient uptake}

The application of $100 \%$ RDF with biocompost and biofertilizer found significantly maximum in case of macro nutrient $\left(\mathrm{N}, \mathrm{P}_{2} \mathrm{O}_{5}, \mathrm{~K}_{2} \mathrm{O}\right)$ and micro nutrient (Fe, $\mathrm{Mn}, \mathrm{Zn}$ and $\mathrm{Cu}$ ) uptake (Table 4). Among the interactions, fertilizer levels and biofertilizer found significant for $\mathrm{N}, \mathrm{P}_{2} \mathrm{O}_{5}, \mathrm{Fe}$, $\mathrm{Mn}, \mathrm{Zn}$ and $\mathrm{Cu}$ uptake (Table 5). The increased nitrogen uptake with nitrogen fertilization was due to the fact that, soil was unable to supply required quantities of nitrogen for optimum growth therefore application of nitrogen fertilizers made up this deficiency which was ultimately reflected in improvement of nitrogen status of the plant. The increased nitrogen uptake was also due to combined application of inorganic fertilizer, biocompost and biofertilizer could be attributed to the favourable effect of biocompost and biofertilizer on microbial activity and root proliferation in soil caused solubilisation effect on native nutrients, which ultimately results in increased nitrogen availability and its concentration in fodder sorghum, thus favouring its higher uptake. The similar results were found by other researchers (Jat et al., 2013; Somashekhar et al., 2014; Chaudhary et al., 2018 and Patel et al., 2018).
From one year experiment, it can be concluded that the application of $100 \%$ RDF with biocompost and biofrtilizer significantly increased macro and micro nutrient content and uptake over the rest of treatments.

\section{References}

Bhoya, M., Chaudhari, P.P., Raval, C.H. and Bhatt P.(2013) Effect of nitrogen and zinc on yield and quality of fodder sorghum [sorghum bicolor(L.) Moench] varieties. Forage Research. 39 (1):2426.

Chaudhary, JD., Pavaya, R.P., Malav, J.K., Dipika, G., Chaudhary, N. and Kuniya NK(2018). Effect of nitrogen and potassium on yield, nutrient content and uptake by forage sorghum [Sorghum bicolor (L.) Moench] on loamy sand. International Journal of Chemical Studies. 6(2):761-765.

Duhan, BS.(2013). Effect of integrated nutrient management on yield and nutrients uptake by sorghum [Sorghum bicolour (L.) Moench]. Forage Research. 39(3):156-158.

Ghuman, B.S. and Sur, H.S.(2006). Effect of manuring on soil properties and yield of rainfed wheat. Journal of the Indian Society of Soil Science. 54(1): 6-11.

Jackson, ML.(1973). Soil chemical analysis. 
Prentice Hall of India Private Limited, New Delhi: 498.

Jat, MK., Purohit, HS., Singh, B., Garhwal, RS. and Choudhary, M. (2013). Effect of integrated nutrient management on yield and nutrient uptake in sorghum [Sorghum bicolor(L.) Moench]. Indian Journal of Agronomy. 58(4): 543-547.

Kumar, R., Singh, P. and Sumeriya, HK. (2010) Effect of integrated nutrient management on growth and productivity of forage sorghum [Sorghum bicolar (L.) Moench]. Forage Research. 36(1):19-21.

Lindsay, WL. and Norvell, WA. (1978). Development of DTPA soil test method for $\mathrm{Zn}, \mathrm{Fe}, \mathrm{Mn}$ and $\mathrm{Cu}$. Soil Science Society of America Journal. 42: 421428.

Patel, KM., Patel, DM., Gelot, D.G. and Patel, I.M. (2018). Effect of integrated nutrient management on green forage yield, quality and nutrient uptake of fodder sorghum [Sorghum bicolor (L.) Moench]. International Journal of Conservation Science. 6(1):173-176.

Patidar, M. and Mali, A. (2004). Effect of farmyard manure, fertility levels and bio-fertilizers on growth, yield and quality of sorghum (Sorghum bicolor). Indian Journal of Agronomy. 49(2): $117-120$.
Rakshit, A., Sarka,r N.C. and Sen, D.(2008). Influence of organic manures on productivity of two varieties of rice. Journal of Central European Agriculture. 9(4): 629-634.

Shekara, B.J., Lohithaswa, H.C. and Pavan R.(2009) Effect of different sources of nutrients on green forage yield and quality of multicut fodder sorghum [Sorghum bicolor (L.) Moench]. Forage Research. 35(3): 137-142.

Singh, A. and Kang JS.(2005). Effect of N with or without FYM on the herbage yield of multi-cut hybrid bajra. Crop Research. 29:401-405.

Singh, N. and Sharma, SK. (2015). Studies on ESP and nitrogen levels and their interaction effect on forage sorghum yield, protein and nutrient uptake. Forage Research. 41(2):95-103.

Somashekar, B.G., Shekara, K.N., Murty, K. and Harish, L.(2014) Yield, nitrogen uptake available soil nutrients and economics of multicut fodder sorghum [Sorghum sudnense (L.) Moench] to different seed rate and nitrogen levels. Forage Research. 40(1): 23-27.

Wenzel, W.G. and Van, Rooyen, P.J.(2011). Moisture stress and potential sorghum yield. International Sorghum and Millets Newsletter. 42: 28-29.

\section{How to cite this article:}

Chauhan Aditi, Sonal Tripathi, Govind, Satdev and Narendra Singh. 2019. Effect of Fertilizer Levels, Biocompost and Biofertilizer on Content and Uptake of Nutrients of Fodder Sorghum (Sorghum bicolor (L.) Moench). Int.J.Curr.Microbiol.App.Sci. 8(10): 1130-1136. doi: https://doi.org/10.20546/ijcmas.2019.810.132 